\title{
PENGARUH BRAND IMAGE TERHADAP KEPUTUSAN PEMBELIAN AIR MINUM DALAM KEMASAN MEREK LE MINERALE Andreas Ronitua ${ }^{1)}$, Lenny Brida $^{2)}$ dan Husnil Barry ${ }^{3)}$ \\ Jurusan Administrasi Niaga Politeknik Negeri Jakarta \\ Email: ${ }^{1}$ tambunanandre@ymail.com, $\underline{2}$ lennybrida@gmail.com,$\underline{3}$ husnil.barry71@gmail.com
}

\begin{abstract}
The Influence of Brand Image Towards Consumer Buying Decision in Drinking Water In Packaging Brand of Le Minerale (Case Study at State Polytechnic of Jakarta Department of Business Administration). This research aims to understand the influence of brand image implanted by Le Minerale towards consumer buying decision among department of business administration student, State Polytechnic of Jakarta with the number of respondents as many as 87 students in described according to gender, study program, and semester. This research using two variables, i.e brand image variable as independent variable (freely) with use of three indicators research, that is Favorability of Brand Association, Strength of Brand Association, and Uniquesness of Brand Image. And consumer buying decision variable as the dependent variable (bound) with use of four indicators research, that is Problem Identification, Information Search, Alternate Evaluation, and Purchase Decision. The regression equation in this research is $Y=46,736+0,535 X$. Based on the results of the analysis simple correlation obtained correlation is 0,515 which means there is a moderate relationship with a positive because the value of $R$ positive. While based on the results of determination index shows that brand image has an effect of $26.5 \%$ of the purchase decision and remaining $73.5 \%$ influenced by other factors.
\end{abstract}

Keywords: Brand Image, Consumer Buying Decision, Favorability, Strength and Uniqueness..

\section{Abstrak}

Pengaruh Brand Image Terhadap Keputusan Pembelian Air Minum Dalam Kemasan Merek Le Minerale (Studi Kasus pada Mahasiswa Administrasi Niaga Politeknik Negeri Jakarta). Penelitian ini betujuan untuk mengetahui pengaruh brand image yang ditanamkan oleh Le Minerale terhadap keputusan pembelian di kalangan mahasiswa Jurusan Administrasi Niaga Politeknik Negeri Jakarta dengan jumlah responden sebanyak 87 orang mahasiswa yang di deskripsikan menurut jenis kelamin, program studi, dan semester. Penelitian ini menggunakan dua variabel, yaitu variabel brand image sebagai variabel independent (bebas) dengan menggunakan tiga indikator penelitian, yaitu Keunggulan Asosiasi Merek, Kekuatan Asosiasi Merek, dan Keunikan Asosiasi Merek. Dan variabel keputusan pembelian sebagai variabel dependent (terikat) dengan menggunakan empat indikator penelitian, yaitu Pengenalan Masalah, Pencarian Informasi, Evaluasi Alternatif, dan Keputusan Pembelian. Persamaan regresi pada penelitian ini adalah $Y=46,736+0,535 X$. Berdasarkan hasil analisis korelasi sederhana didapatkan korelasi yakni 0,515 yang berarti terjadi hubungan yang sedang dengan hubungan yang positif karena nilai $R$ positif. Sedangkan berdasarkan hasil indeks determinasi menunjukan bahwa promosi penjualan memiliki pengaruh sebesar 26,5\% terhadap proses keputusan pembelian dan sisanya 73,5\% dipengaruhi oleh faktor lain.

Kata Kunci: Brand Image, Keputusan Pembelian, Keunggulan, Kekuatan, dan Keunikan.

\section{PENDAHULUAN}

\section{Latar Belakang}

Air merupakan salah satu kebutuhan hidup manusia yang sangat penting bagi tubuh. Salah satu cara untuk mengatasi masalah perolehan air bersih, aman, dan sehat terutama di kota-kota besar adalah melalui produksi Air Minum Dalam Kemasan (AMDK). Kebutuhan yang besar akan air tersebut dibaca oleh perusahaan untuk memproduksi air minum dalam kemasan. Kini perusahaan yang bergerak dalam bisnis Air Minum Dalam Kemasan (AMDK) semakin bertambah dan 
memperluas jaringan pemasarannya sehingga tingkat persaingan semakin ketat. Kondisi ini menuntut setiap perusahaan untuk berusaha keras dalam berinovasi, kreatif menciptakan dan mengembangkan produk, ukuran, dan kemasan yang berbeda sesuai dengan kebutuhan konsumen.

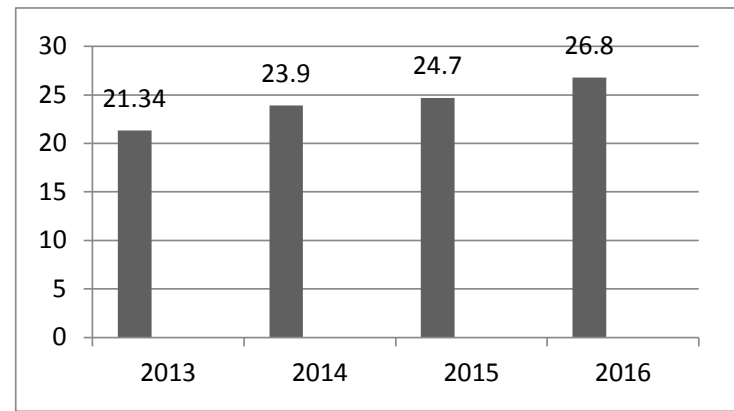

Gambar 1. Produksi Air Minum Dalam Kemasan di Indonesia (miliar liter) Sumber: Aspadin, 2016

Dengan total perusahaan AMDK yang ada di Indonesia tersebut maka persaingan bisnis pada era saat ini semakin ketat, sehingga menuntut perusahaan untuk berkembang dan meningkatkan keunggulannya secara kompetitif. Agar dapat bertahan dalam persaingan tersebut, selain diperlukan pengelolaan manajemen yang baik, dibutuhkan juga strategi untuk menciptakan dan mempertahankan konsumen yang loyal. Salah satu peranan yang sangat penting dalam strategi pemasaran adalah merek.

Kini, merek bukan hanya dianggap sebagai nama, logo atau simbol tetapi merupakan nilai yang ditawarkan sebuah produk bagi konsumen yang memakainya. Perusahaan melakukan berbagai upaya dalam rangka mempertahankan citra merek (brand image) yang mereka miliki diantaranya keunggulan teknologi yang dimiliki produk tersebut, penetapan harga yang bersaing, dan promosi yang tepat sasaran akan mempengaruhi keputusan pembelian konsumen.

Berdasarkan uraian diatas, maka dapat diketahui bahwa citra merek memiliki posisi strategis dalam persaingan yang tidak dapat diabaikan oleh perusahaan dalam menarik konsumen untuk menggunakan produknya. Mengingat pentingnya brand image yang dapat mempengaruhi keputusan pembelian, maka penulis tertarik untuk melakukan penelitian dengan judul "Pengaruh Brand Image terhadap Keputusan Pembelian Air Minum Dalam Kemasan Merek Le Minerale (Studi Kasus pada Mahasiswa Administrasi Niaga Politeknik Negeri Jakarta)”

\section{METODE PENELITIAN}

Penelitian ini dilakukan di PNJ dan dilakukan selama delapan bulan dengan beberapa tahapan yaitu; (1) Tahap Perencanaan; dimana pada tahap ini dilakukan pengumpulan kosakata yang sering digunakan dan dapat dituangkan dalam model latihan, perencanaan aplikasi software dan perencanaan model latihan serta evaluasi; (2) Tahap analisis. Pada tahap ini data-data yang telah terkumpul dianalisis dan diidentifikasi dengan mendapatkan hasil modul yang sesuai dengan target. Analisis dilakukan juga terhadap pola evaluasi yang akan diterapkan; (3) Tahap Perancangan Kegiatan. Pada tahap ini dilakukan desain pembelajaran yang sesuai dan penentuan isi materi modul latih serta tampilan; (4) Tahap Pelaksanaan Kegiatan. Pada tahap ini berupa pelkasanaan kegiatan pembuatan bahan ajar, pembuatan animasi dan uji coba modul.

\section{Tujuan}

Analisis seberapa besar pengaruh profotabilitas, likuiditas dan solvabilitas dalam memprediksi kondisi dimana perusahaan dikatakan dalam kondisi financial distress yang memungkinkan perusahaan mengalami kebangkrutan.

\section{Permasalahan}

Apakah analisis profitabilitas, likuiditas dan solvabilitas dapat memprediksi financial distress pada perusahaan yang 
selalu tercatat dalam LQ45 pada tahun 2013-2016?

\section{Kajian Pustaka \\ Pengertian Brand}

Menurut American Marketing

Association dalam Kotler (2009:258) brand adalah nama, istilah, tanda, lambang, atau desain, atau kombinasinya, yang dimaksudkan untuk mengidentifikasikan barang atau jasa dari salah satu penjual atau kelompok penjual dan mendiferensiasikan mereka dari para pesaing.

\section{Pengertian Brand Image}

Menurut Ferrinadewi (2008:165) berpendapat bahwa brand image adalah persepsi tentang merek yang merupakan refleksi memori konsumen akan asosiasinya pada merek tersebut. Dapat juga dikatakan bahwa brand image merupakan konsep yang diciptakan oleh konsumen karena alasan subyektif dan emosi pribadinya. Oleh karena itu dalam konsep ini persepsi konsumen menjadi lebih penting daripada keadaan sesungguhnya.

\section{Komponen Brand Image}

Keller (dalam Romadhoni, 2015: 11) mengemukakan faktor-faktor terbentuknya citra merek atara lain:

a. Keunggulan merek merupakan salah satu faktor pembentuk brand image, dimana produk tersebut unggul dalam persaingan. Karena keunggulan kualitas (model dan kenyamanan) dan ciri khas itulah yang menyebabkan suatu produk mempunyai daya tarik tersendiri bagi konsumen.

b. Kekuatan merek merupakan asosiasi merek tergantung pada bagaimana informasi masuk kedalam ingatan konsumen dan bagaimana proses bertahan sebagai bagian dari citra merek. Kekuatan asosiasi merek ini merupakan fungsi dari jumlah pengolahan informasi yang diterima pada proses ecoding. c. Keunikan merek adalah asosiasi terhadap suatu merek mau tidak mau harus terbagi dengan merek-merek lain. Oleh karena itu, harus diciptakan keunggulan bersaing yang dapat dijadikan alasan bagi konsumen untuk memilih suatu merek tertentu. Dengan memposisi- kan merek lebih mengarah kepada pengalaman atau keuntungan diri dari image produk tersebut.

\section{Proses Keputusan Pembelian}

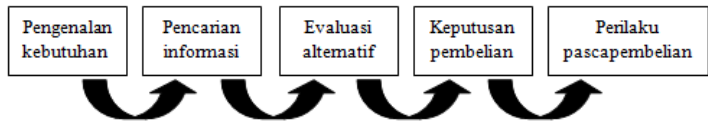

Gambar 2 : Proses Keputusan Pembelian. Sumber : Abdurrahman (2015:41)

1. Pengenalan kebutuhan

Pengenalan kebutuhan adalah tahap pertama proses keputusan pembelian, yaitu konsumen menyadari suatu masalah atau kebutuhan.

2. Pencarian informasi

Pencarian informasi adalah tahap proses kebutuhan pembeli dengan cara mencari informasi lebih banyak. Konsumen mungkin hanya memperbesar perhatian atau melakukan pencarian informasi secara aktif.

3. Evaluasi alternatif

Evaluasi alternatif adalah tahap proses keputusan membeli konsumen dengan menggunakan informasi untuk mengevaluasi merek alternatif dalam sekelompok pilihan.

4. Keputusan pembelian

Keputusan pembelian yaitu keputusan konsumen untuk membeli atau tidak membeli suatu produk atau jasa merupakan alternatif pilihan yang penting bagi pemasar.

5. Perilaku pascapembelian

Perilaku pascapembelian adalah tahap proses keputusan pembeli, yaitu konsumen mengambil tindakan selanjutnya setelah pembelian, berdasarkan kepuasan atau ketidakpuasan konsumen. 


\section{METODE PENELITIAN}

Variabel-variabel yang digunakan dalam penelitian ini adalah Brand Image (X) sebagai variabel bebas. Sedangkan Keputusan Pembelian (Y) sebagai variabel terikat.

\section{Populasi dan Sampel}

Menurut Sugiyono (2012:90) populasi adalah wilayah generalisasi yang terdiri atas obyek/subyek yang mempunya kualitas dan karakteristik tertentu yang ditetapkan oleh peneliti untuk dipelajari dan kemudian ditarik kesimpulannya. Sedangkan sampel adalah bagian dari jumlah dan karakteristik yang dimiliki oleh populasi tersebut (Sugiono, 2016:81).

\section{Populasi}

Populasi yang akan diamati dalam penelitian ini adalah mahasiswa Administrasi Niaga Politeknik Negeri Jakarta yang pernah mengkonsumsi Le Minerale. Jumlah populasi sebanyak 687 mahasiswa.

\section{Sampel}

Populasi yang digunakan terdiri dari beberapa program studi yaitu Administrasi Bisnis, Administrasi Bisnis Terapan, dan MICE. Ketiga program studi tersebut memiliki strata yang berbeda, maka dari itu untuk mengetahui jumlah sampel yang digunakan maka penulis menggunakan rumus Slovin sebagai acuan dalam menentukan jumlah sampel.

$$
\mathrm{n}=\frac{N}{N \cdot \mathrm{d}^{2}+1}=\frac{687}{687 \cdot 0,1^{2}+1}=\frac{687}{7,87}=87
$$

\section{HASIL DAN PEMBAHASAN}

Hasil penelitian dan pembahasan menggunakan program SPS 24.0 (Statistical Program for Social Science). Uji yang dilakukan antara lain uji instrumen (uji validitas dan uji reliabilitas), uji asumsi klasik (uji normalitas dan uji linearitas), dan uji hipotesis (analisis regresi linear sederhana, koefisien korelasi sederhana, koefisien determinasti, dan uji signifikansi).

\section{Uji Validitas}

Tabel 1 Hasil Uji Validitas
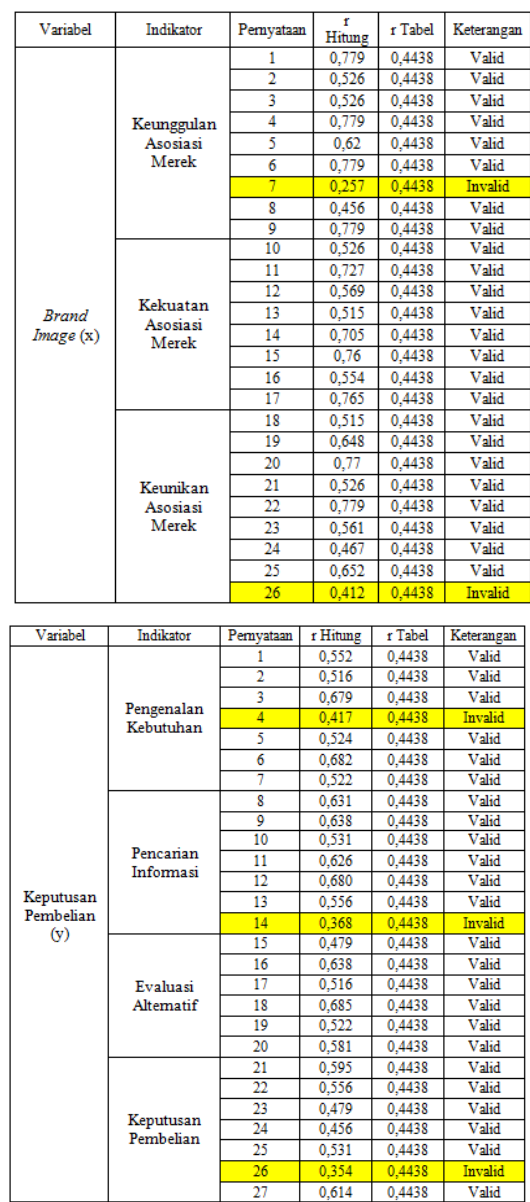

Sumber: Data Diolah, 2017

Hasil uji validitas menunjukkan bahwa tidak semua butir pernyataan pada variabel brand image (X) dan keputusan pembelian (Y) memiliki nilai $r$ hitung lebih besar dari nilai $\mathrm{r}$ table. Terdapat 5 butir pernyataan yang tidak memenuhi uji validitas. Dengan demikian, dapat disimpulkan bahwa terdapat 50 butir pernyataan pada instrument yang dapat dilanjutkan dalam penelitian lapangan. 
Uji Reliabilitas

Tabel 2 Hasil Uji Reliabilitas

Reliability Statistics
Brand Image

Berdasarkan hasil dari uji reliabilitas dapat dilihat bahwa variabel brand image (X) dan keputusan pembelian (Y) memiliki koefisien reliabilitas yaitu sebesar 0,752 dan 0,746. Hal ini menunjukkan bahwa kedua variabel reliabel karena memiliki nilai koefisien reliabilitas di atas 0,6. dan dapat diterima untuk dilanjutkan dalam penelitian lapangan.

Uji Normalitas

Tabel 3. Hasil Uji Normalitas

\begin{tabular}{llr}
\multicolumn{2}{c}{ One-Sample Kolmogorov-Smirnov Test } \\
\hline & & $\begin{array}{r}\text { Unstandardize } \\
\text { d Residual }\end{array}$ \\
\hline $\mathrm{N}$ & & 87 \\
Normal Parameters ${ }^{\mathrm{a}, \mathrm{b}}$ & Mean &, 0000000 \\
& Std. Deviation & 7,09542668 \\
Most Extreme Differences & Absolute &, 067 \\
& Positive &, 067 \\
& Negative &,- 064 \\
Test Statistic & &, 067 \\
Asymp. Sig. (2-tailed) & &, $200^{\mathrm{c}, \mathrm{d}}$ \\
& &
\end{tabular}

Sumber: Data Diolah, 2017

Berdasarkan tabel di atas dapat diketahui bahwa probabilitas (sig) yang diperoleh yaitu 0,200. Nilai probabilitas (sig) tersebut lebih besar dari taraf signifikansi penelitian yaitu $10 \%(0,10)$. Dengan demikian, dapat disimpulkan bahwa berdasarkan uji normalitas kolmogorov-smirnov data berdistribusi normal.

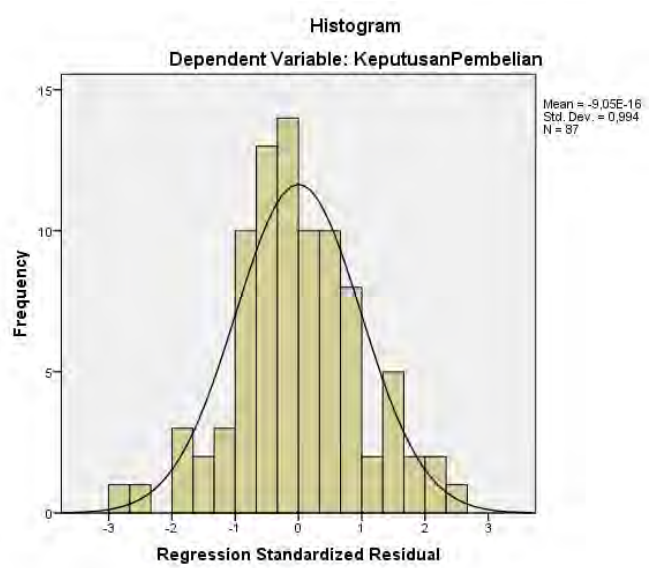

Gambar 3. Grafik Histogram. Sumber Data Diolah,

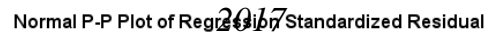

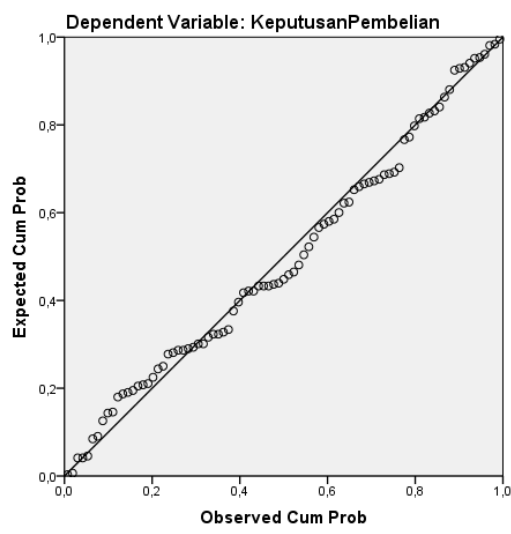

Gambar4. Grafik P-Plot. Sumber Data Diolah, 2017

Dengan melihat tampilan grafik histogram maupun grafik normal p-p plot dapat disimpulkan bahwa grafik histogram memberikan pola distribusi yang mendekati normal. Sedangkan pada grafik normal p-p plot terlihat titik-titik menyebar di sekitar garis diagonal. Kedua gambar grafik ini menunjukan bahwa model regresi layak dipakai karena memenuhi asumsi normalitas.

\section{Uji Linearitas}

Tabel 4. Hasil Uji Heteroskedastisitas

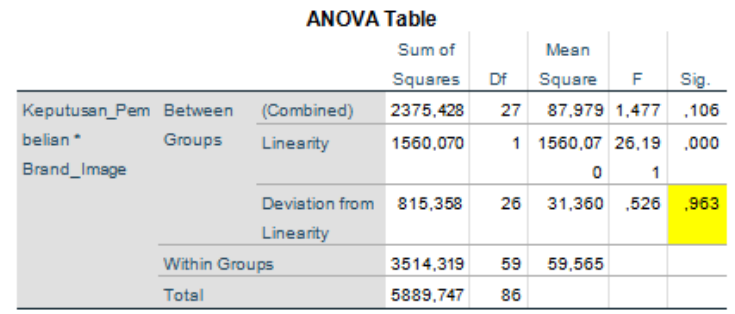

Sumber: Data Diolah, 2017

Berdasarkan tabe di atas dapat dilihat bahwa diperoleh probabilitas $=0,963>$ 
0,05, maka dapat disimpulkan bahwa antara brand image dengan keputusan pembelian mempunyai hubungan yang linear.

\section{Analisis Regresi Linear Sederhana}

Tabel 5. Analisis Regrêsqvinear Sederhana

\begin{tabular}{l|l|r|r|r|r|r|}
\hline \multicolumn{1}{l}{ Model } & & Sum of Squares & Df & Mesn Square & F & Sig. \\
\cline { 2 - 7 } & Regression & 1560,070 & 1 & 1560,070 & 30,627 & $.000^{\circ}$ \\
\cline { 2 - 7 } & Residual & 4329,677 & 85 & 50,937 & & \\
\cline { 2 - 7 } & Total & 5889,747 & 86 & & & \\
\hline
\end{tabular}

\section{Sumber : Data diolah, 2017}

Dari hasil perhitungan yang ditelah dilakukan diperoleh harga Fhitung $(30,627)>$ Ftabel $(3,95)$ dan nilai signifikansi sebesar 0,000 atau lebih kecil dari 0,05. Berdasarkan hasil tersebut dapat dikatakan bahwa koefisien dari kedua variabel tersebut signifikan, atau dengan kata lain variabel brand image berpengaruh terhadap variabel keputusan pembelian.

Tabel 6. Koefisien Regresidtinear Sederhana

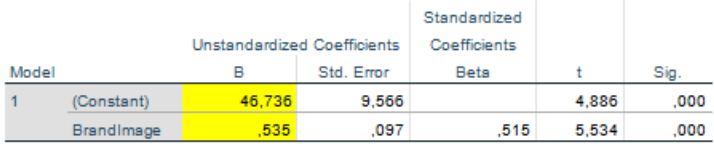

Sumber : Data diolah, 2017

Berdasarkan tabel di atas maka persamaan regresi yang diperoleh pada penelitian ini, yaitu:

$$
Y=46,736+0,535 X
$$

Penjelasan persamaan regresi di atas yaitu nilai konstanta yang diperoleh pada penelitian ini sebesar 46,736, artinya jika brand image (X) nilainya 0, maka keputusan pembelian (Y) nilainya adalah 46,736. Nilai koefisien arah regresi pada penelitian ini yaitu positif 0,535 , artinya jika ada penambahan satu angka pada brand image $(\mathrm{X})$ maka akan ada kenaikan pada variabel keputusan pembelian (Y) sebesar 0,535 .

\section{Koefisien Korelasi Sederhana}

Correlations

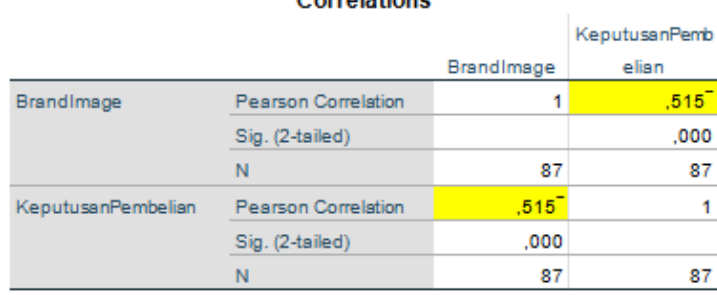

Gambar 5. Koefisien Korelasi Sederhana Sumber : Data diolah

Berdasarkan table di atas dapat disimpulkan bahwa nilai koefisien tersebut menunjukkan adanya korelasi yang cukup berarti antara brand image dengan proses keputusan pembelian. Koefisien korelasi Pearson tersebut lebih besar dari nol atau $0,515>0$ artinya telah terjadi hubungan linier yang positif. Koefisien korelasi pearson tersebut masuk dalam kelas interval sedang yaitu 0.515 termasuk dalam rentang 0,40 - 0,515 yang artinya tingkat hubungan antara brand image terhadap keputusan pembelian air minum dalam kemasan masuk dalam kategori sedang.

\section{Koefisien Determinasi}

Tabel 7. Hasil Koefisien Determinasi Correlations

\begin{tabular}{|c|c|c|c|}
\hline & & Brandlmage & $\begin{array}{c}\text { KeputusenPemb } \\
\text { elian }\end{array}$ \\
\hline \multirow[t]{3}{*}{ Brandlmage } & Pearson Correlation & 1 & $.515^{-}$ \\
\hline & Sig. (2-tailed) & & .000 \\
\hline & $\mathrm{N}$ & 87 & 87 \\
\hline \multirow[t]{3}{*}{ KeputusanPembelian } & Pearson Correlation & $.515^{-}$ & 1 \\
\hline & Sig. (2-tailed) & .000 & \\
\hline & $\mathrm{N}$ & 87 & 87 \\
\hline
\end{tabular}

Berdasarkan hasil perhitungan regresi menunjukan bahwa nilai $R$ Square adalah sebesar 0,265. Hal tersebut menjelaskan bahwa sebesar 26,5\% keputusan pembelian air minum dalam kemasan merek Le Minerale pada mahasiswa jurusan Administrasi Niaga Politeknik Negeri Jakarta dipengaruhi oleh variabel independen penelitian ini, yaitu brand image. Sedangkan sebesar 73,5\% sisanya dipengaruhi oleh faktor lain yang tidak diteliti pada penelitian ini. 
Uji T (Uji Signifikansi)

Tabel 8. Hasil Uji T

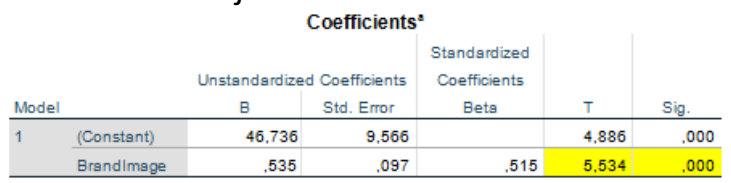

Sumber : Data diolah

Dari tabel di atas dapat diketahui nilai Thitung yaitu 11,709. Selanjutnya Thitung akan dibandingkan dengan nilai Ttabel dengan nilai signifikansi kesalahan 5\% dimana Ttabel didapat dari rumus $\mathrm{df}=\mathrm{n}-\mathrm{k}$, dimana df adalah derajat kebebasan, $\mathrm{n}$ adalah jumlah responden dan $\mathrm{k}$ adalah jumlah variabel yang akan diteliti. Selanjutnya didapat Ttabel 1,6630. Sehingga dapat dilihat nilai Thitung variabel X lebih besar dari Ttabel atau 5,534 > 1,6630 yang artinya variabel brand image berpengaruh terhadap variabel keputusan pembelian. Kemudian didapat nilai signifikansi $0,000<0,05$ dan dapat disimpulkan bahwa ada pengaruh yang nyata (signifikan) variabel $\mathrm{X}$ (brand image) terhadap variabel $\mathrm{Y}$ (keputusan pembelian).

\section{KESIMPULAN DAN SARAN}

Berdasarkan penelitian tentang Pengaruh Brand Image terhadap Keputusan Pembelian Air Minum Dalam Kemasan Merek Le Minerale (Studi Kasus pada mahasiswa Administrasi Niaga), maka dapat disimpulkan sebagai berikut :

a. Berdasarkan hasil penelitian yang didapat maka terdapat dua indikator dalam brand image yang paling berpengaruh, yaitu kekuatan asosiasi merek dan keunikan asosiasi merek. Hal tersebut dapat dilihat berdasarkan rekapitulasi jawaban responden yang didominasi dengan kategori Sangat Setuju.

b. Berdasarkan penelitian langsung dengan para responden, terdapat beberapa faktor lain yang juga memengaruhi keputusan pembelian air minum dalam kemasan merek Le Minerale, yaitu harga dan kualitas produk. Disebabkan karena harga Le Minerale terjangkau dan lebih murah dibanding kompetitor lain, namun tetap memperhatikan kualitas air minum yang berkualitas yang ditandai dengan penggunaan teknologi Mineral Protection System yang berfungsi untuk menjaga kesegaran pada kemasan.

c. Berdasarkan uji t dalam penelitian ini, terdapat pengaruh yang signifikan antara brand image Le Minerale terhadap keputusan pembelian. Hal ini dapat dilihat dari hasil uji signifikasi pada tabel 4.19 di mana thitung $=5,534$ $>$ ttabel $=1,6630$. Dengan demikian Ha diterima dan Ho ditolak, atau dapat disimpulkan bahwa brand image (X) mempunyai pengaruh secara signifikan terhadap variabel keputusan pembelian (Y). Hal ini menyatakan bahwa hipotesis diterima.

d.

\section{DAFTAR PUSTAKA}

\section{Buku}

Abdurrahman, Nana Herdiana. 2015. Manajemen Strategi Pemasaran. Bandung : Pustaka Setia.

Ambadar, Jackie dkk. 2007. Mengelola Merek. Jakarta : Yayasan Bina Karsa Mandiri.

Ferrinadewi, Erna. 2008. Merek dan Psikologi Konsumen. Yogyakarta : Graha Ilmu.

Kotler, Philip dan Kevin Lane Keller. 2009. Manajemen Pemasaran, Edisi Ketiga Belas Jilid 1. Terjemahan oleh Bob Sabran dari Marketing Management, Thirteenth Edition. Jakarta : Penerbit Erlangga. 2009. Manajemen Pemasaran, Edisi Ketiga Belas Jilid 2. Terjemahan oleh Bob Sabran dari Marketing Management, Thirteenth Edition. Jakarta : Penerbit Erlangga.

Priyatno, Duwi. 2011. Buku Saku Analisis Statistik Data SPSS. Yogyakarta : Mediakom. 
Sugiyono. 2013. 2016. Metode Penelitian

Kuantitatif, Kualitatif dan R\&D.

Bandung : Alfabeta.

2016. Metode Penelitian

Kuantitatif, Kualitatif dan R\&D.

Bandung : Alfabeta.

Sunyoto, Danang. 2012. Dasar-dasar

Manajemen Pemasaran. Yogyakarta :

CAPS.

Tjiptono, Fandy. 2015. Strategi Pemasaran

Edisi 4. Yogyakarta : Andi Offset.

. 2014. Branding \& Brand

Longevity di Indonesia. Yogyakarta

:Andi Offset.Keown, Arthur J dkk.

2011. Manajemen Keuangan.

Jakarta: PT Indeks.

\section{Jurnal}

Khoiriah. 2013. “Analisis Pengaruh Citra

Merek Terhadap Keputusan

Pembelian Air Minum Dalam

Kemasan Merek Aqua (Studi Kasus

Warga Jatibening)”. Dalam Jurnal

Bisnis Universitas Gunadarma Vol.

22 No.1, Bekasi.

Kristina, Eka dkk. 2015. "Pengaruh Brand Image Terhadap Keputusan Pembelian pada Konsumen Air Minum Dalam Kemasan (AMDK) Barokah "Al-Qodiri" di Kabupaten Jember”. Dalam Jurnal Ekonomi Bisnis Vol. 2 No. 1, Jember.

Murty, Dea. 2015. “Analisis Pengaruh Harga, Kualitas Produk dan Citra Merek Terhadap Keputusan Pembelian Air Minum Dalam Kemasan Merek Pelangi Kemasan 600ML di Semarang”. Dalam Jurnal Ekonomika dan Bisnis Universitas Diponegoro, Vol. 4 No. 2, Semarang.

Nur, Fitriani. 2016. "Pengaruh Brand Image (Citra Merek) dengan Minat Minat Beli Konsumen pada Air Minum Dalam Kemasan Aqua”.

Selestio, Robby. 2013. “Analisis Pengaruh Citra Merek, Kualitas Produk dan Promosi Terhadap Keputusan Pembelian Air Minum Dalam Kemasan (AMDK) Merek Oasis”.
Dalam Jurnal Ekonomika dan Bisnis Universitas Diponegoro, Vol. 12, No. 4, Semarang.

\section{Internet}

Amna, Muhammad Abdi. 2016. "Industri Air Minum Kemasan Indonesia Bisa Jadi yang Terbesar di ASEAN.” (http://www.industri.bisnis.com diakses 13 April 2017).

Marketeers. 2015. "Industri Air Minum di Indonesia Tak Pernah Paceklik." (http://www.marketeers.com diakses 13 April 2017).

Romadhoni, Muhammad. 2015. "Pengaruh Citra Merek (Brand Image) Terhadap Pengambilan Keputusan Pembelian Sepatu Nike pada Mahasiswa FIK UNY” (http://eprints.uny.ac.id diakses 16 April 2017) 